\title{
LATE PLIOCENE ABRASION PLATFORM FROM THE CANTIL COSTERO FORMATION OF BAJA CALIFORNIA
}

\section{PLATAFORMA DE ABRASION DEL PLIOCENO TARDIO DENTRO DE LA FORMACION CANTIL COSTERO DE BAJA CALIFORNIA}

\author{
Jorge Ledesma-Vázquez ${ }^{1}$ \\ Markes E. Johnson ${ }^{2}$ \\ ' Facultad de Ciencias Marinas \\ Universidad Autónoma de Baja California \\ Apartado postal 453 \\ Ensenada, Baja California, México \\ ${ }^{2}$ Department of Geology \\ Williams College \\ Williamstown, MA 01267, USA
}

Recibido en octubre de 1993; aceptado en marzo de 1994

\begin{abstract}
An unusually extensive and well preserved marine abrasion platform of Late Pliocene age is present $84 \mathrm{~m}$ above sea level north of El Rosario, in Baja California. The surface extends for $6 \mathrm{~km}$ along the coast and is up to $3 \mathrm{~km}$ wide. The abrasion platform is a major disconformity that separates siltstones of the Upper Cretaceous Rosario Formation from the basal conglomerates of the Upper Pliocene Cantil Costero Formation. During its creation under transgressive conditions, the platform was kept clear of nearshore sediments and colonies of the pholadid bivalve Penitella penita (Conrad, 1837 ) with densities of up to $200 / \mathrm{m}^{2}$, bored into the underlying platform rocks. Tectonic uplift of the peninsula and the Sierra San Pedro Mártir, starting about 2 m.y. ago, stimulated a massive progradation of land-derived clastics, which inundated the platform and locally exterminated the pholadid bivalves. This example clearly illustrates a model of transition from subtidal to intertidal conditions, in contrast to unconformities of strictly submarine origin.
\end{abstract}

Key words: abrasion platform, disconformity, ancient rocky shore, Pholadidae (bivalves).

\section{RESUMEN}

Cerca de El Rosario, Baja California, a $84 \mathrm{~m}$ sobre el nivel del mar, se encuentra excelentemente preservada una plataforma de abrasión de origen marino a la que se asigna edad del Plioceno tardío. La superficie se extiende $6 \mathrm{~km}$ a lo largo de la costa y más de $3 \mathrm{~km}$ tierra adentro. Es una gran discordancia paralela que separa las limolitas de la formación Rosario del Cretácico superior de los conglomerados basales de la formación Cantil Costero del Plioceno tardío. Durante la generación de la plataforma bajo condiciones transgresivas, ésta se caracterizó por ser un área libre de sedimentos, sobre la cual se desarrollaron colonias de foládidos bivalvos de Penitella penita (Conrad, 1837), cuya densidad alcanzó hasta 200 perforacioncs por metro cuadrado. El levantamiento tectónico en el bloque de la sierra de San Pedro Martir del Batolito Peninsular, iniciado aproximadamente hace dos milloncs de años. cmpezó un proceso progradacional de los fragmentos derivados de este bloque, los cuales cubrieron la plataforma preexistente y exterminaron localmente los bivalvos foládidos. Este ejemplo 
muestra claramente un modelo de transición de condiciones submareales a intermareales, en contraste con discordancias de origen estríctamente submarino.

Palabras clave: plataforma de abrasión, discordancia, costa rocosa antigua, Pholadidae (bivalvos).

\section{INTRODUCTION}

The purpose of this paper is to describe an emergent marine abrasion platform of Late Pliocene age on the Pacific coast of northern Baja California, north of El Rosario (Mexico). This platform cuts across the Upper Cretaceous Rosario Formation, locally consisting of comparatively soft siltstones. The platform's seaward edge is elevated $84 \mathrm{~m}$ above the present sea level. A stratigraphically lower horizon of the same thick Cretaceous siltstone is at the present time under attack by intertidal erosion on the adjacent shores of the Pacific Ocean. Both the modern and Late Pliocene platforms are bored by colonies of pholadid bivalves.

Such bored disconformable surfaces are often the subject of controversy, with opposing submarine and intertidal models of abrasion. Rose (1970), for example, argued for exclusively submarine origins of some Cretaceous surfaces in Texas. Reviewing the same disconformities, Perkins and Stewart (1971) left the issue open to debate. Lewy (1985) reinterpreted at lcast onc of the Texas surfaces as an intertidal abrasion platform, based on comparison with other bored disconformities of Cretaceous age in Israel. Juxtaposition of modern and ancient environments with respect to the same substrate, allows for an ideal comparison of factors involved in the formation of such an abrasion platform. Several characteristics preserved in this example from Baja California help to distinguish between intertidal and deeper submarine models of platform development.

\section{LOCATION AND GEOLOGIC SETTING}

Coastal Pliocene-Pleistocene strata stretch for about $80 \mathrm{~km}$ between Bahia San Quintín and Punta Baja (Gastil et al., 1971), generally showing characteristics of terrace deposits. The field data and materials upon which this study is based were collected from several localities within an $18 \mathrm{~km}^{2}$ area situated $1 \mathrm{~km}$ inland from

\section{INTRODUCCION}

El propósito de este artículo es describir una plataforma de abrasión marina emergente del Plioceno tardio en la costa del Pacífico del norte de Baja California, al norte de El Rosario (México). Esta plataforma corta la formación Rosario del Cretácico superior, que localmente consiste en lutitas comparativamente suaves. El borde de la plataforma orientado hacia el mar se encuentra a $84 \mathrm{~m}$ snmm, actualmente. Un horizonte estratigráfico subyacente de la misma lutita cretácica de gran espesor está bajo el ataque del oleaje en las costas adyacentes del océano Pacifico. Tanto la plataforma del Plioceno tardío como la moderna se encuentran perforadas por colonias de bivalvos foládidos.

Las superficies discordantes con perforaciones son frecuentemente tema de una controversia que opone los modelos de abrasión intermareales y submarinos. Rose (1970), por ejemplo, apoyó exclusivamente el emplazamiento submarino con respecto a algunas superficies cretácicas de Texas. Al revisar las mismas discordancias, Perkins y Stewart (1971) dejaron el tema abierto a debate. Lewy (1985) reinterpretó por lo menos una de las superficies texanlas como una plataforma intermareal de abrasión, basándose en la comparación con otras discordancias con perforaciones de edad cretácica, de Israel. La yuxtaposición de ambientes modernos y antiguos con respecto al mismo substrato permite una comparación ideal de los factores relacionados en la formación de tales plataformas de abrasión. Varias características preservadas en este ejemplo de Baja California ayudan a distinguir entre el modelo de desarrollo de plataforma intermareal y el exclusivamente marino.

\section{LOCALIZACION Y EMPLAZAMIENTO GEOLOGICO}

Entre bahía San Quintín y punta Baja, a lo largo de $80 \mathrm{~km}$, se presentan estratos costeros 


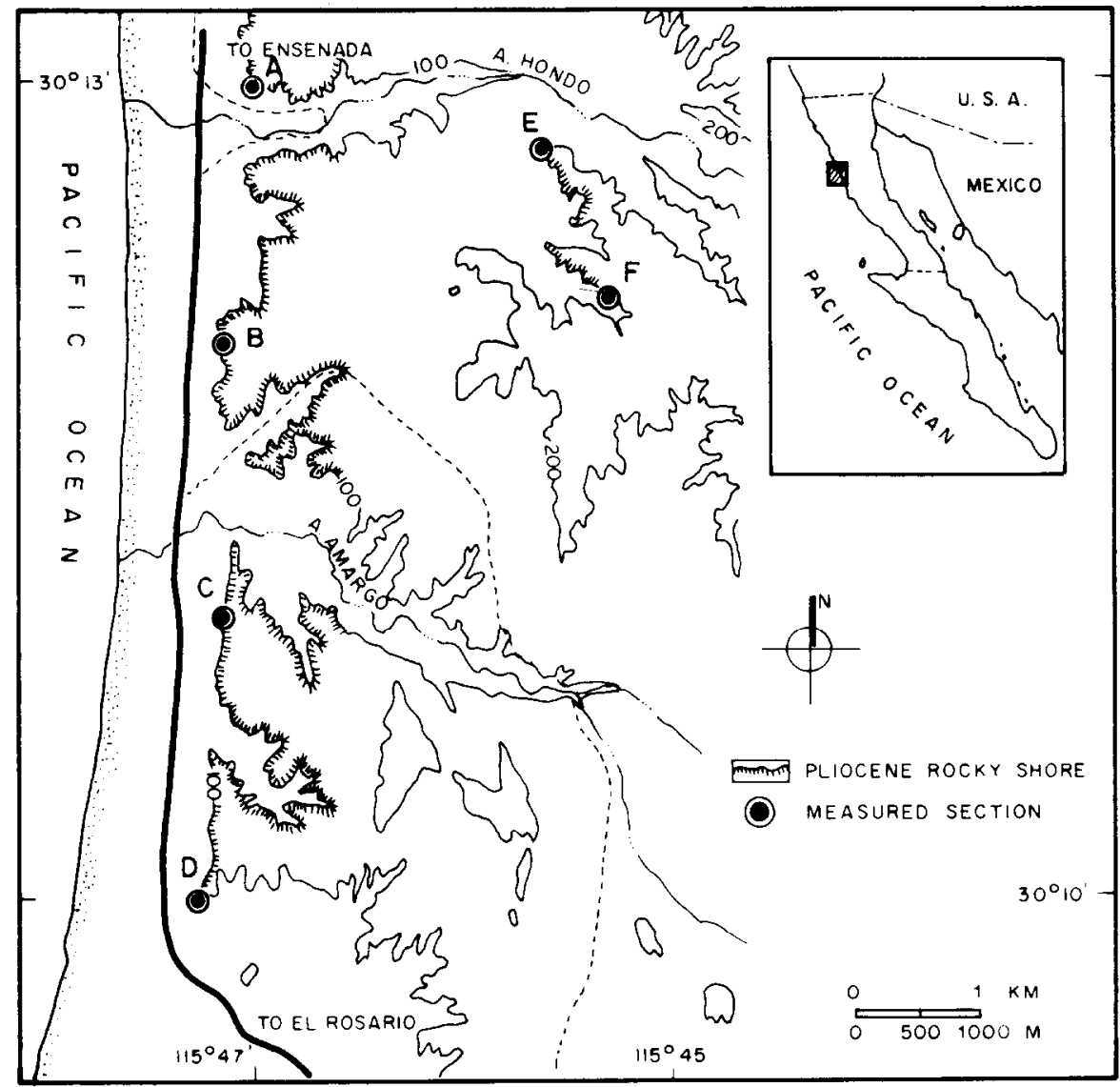

Figure 1. Locality map, showing the Pacific coast of Baja California (Mexico), with a Pliocene-age intertidal abrasion platform. Stations $A$ to $D$ are located on the Pliocene-Cretaceous disconformity above kilometer markers 35, 37, 39 and 41, respectively (Mexican Federal Highway 1). Distance from station D to El Rosario (off map to the south) is $14.5 \mathrm{~km}$.

Figura 1. Mapa de la localidad, que muestra la costa del Pacífico de Baja California, con una plataforma de abrasión intermareal del Plioceno. Las estaciones A a D están localizadas en la discordancia Cretácico-Plioceno, en los km 35, 37, 39 y 41 , respectivamente (carretera federal mexicana 1). La distancia de la estación D a El Rosario (fuera del mapa, al sur) es $14.5 \mathrm{~km}$.

the Pacific coast of Baja California, 14-20 km north of the village of El Rosario and approximately midway between Bahía San Quintín to the north and Punta Baja to the south. A continuous escarpment, reaching elevations of 90-100 $\mathrm{m}$ above sea level, is easily accessible along Mexican Federal Highway 1 (Fig. 1). Exposed therein, at an elevation of $84 \mathrm{~m}$ above sea level, is a sharp disconformity between silt- del Plioceno-Pleistoceno que muestran, en general, características de depósitos de terraza (Gastil et al., 1917). Los datos de campo y materiales en que se basa este estudio fueron tomados de varias localidades dentro de un área de $18 \mathrm{~km}^{2}$, situada $1 \mathrm{~km}$ tierra adentro de la costa del Pacífico de Baja California, de 14 a $20 \mathrm{~km}$ al norte del poblado El Rosario y aproximadamente a media distancia entre bahía San 
stones of the Upper Creteceous Rosario Formation and an overlying cap rock of conglomerate and beach sands that were mapped by Gastil et al. (1971) as the Pliocene Cantil Costero Formation (Fig. 2a). A smaller parallel escarpment exposing the same disconformity occurs $3 \mathrm{~km}$ farther inland.

The Rosario Formation was named and described by Beal (1948). According to the summary by Silver et al. (1963), it is Campanian to Maastrichtian in age. Lithologic composition below unconformities with younger strata is variable from place to place along the Pacific coast. Limestone occurs to the north, near Eréndira (Lescinsky et al, 1991). Conglomerate and sandstone occur in the Camalú-Colonet area (Miller and Abbott, 1989). Plant-bearing terrestrial deposits occur at El Rosario to the south (Kilmer, 1963), where the entire formation is up to $380 \mathrm{~m}$ in thickness. Massive siltstone with a carbonate content of approximately $35 \%$ is the prevailing Cretaceous lithology in the project area. The area was chosen for study especially because of this comparatively soft lithology and its bearing on the local Cretaceous-Pliocene disconformity

The Cantil Costero Formation was described by Santillán and Barrera (1930). The name in Spanish means "coastal cliffs" in reference to the local prominent escarpment. Near the coast, the formation is typically 10 to $12 \mathrm{~m}$ thick, consisting of basal conglomerates overlain by fine-grained "beach" sand. The conglomerates include clasts derived from igneous and metamorphic basement rocks, and Cretaceous and Paleocene strata immediately to the east (Gastil et al., 1975). Tamiosoma gregaria Conrad, 1856 (Zullo, 1992), large barnacles with Pliocene to recent range, are conspicuous reworked elements of the dominant sand-beach facies. Zullo (1992), based on the occurrence of T. gregaria in northern Baja California, finally gave the age of the Cantil Costero Formation as Pliocene rather than Pleistocene, as previously reported by Valentine (1955).

\section{METHOD OF STUDY}

Six outcrops were examined (at stations labeled $\mathrm{A}-\mathrm{F}$ ) as shown in Fig, 1. Four stations
Quintín, al norte, y punta Baja, al sur. Un escarpe continuo que alcanza elevaciones de 90 a $100 \mathrm{~m} \mathrm{snmm}$ es fácilmente accesible, a lo largo de la carretera federal mexicana 1 (Fig. 1). Aquí, a $84 \mathrm{~m}$ snmm, es visible una discordancia aguda entre lutitas de la formación Rosario del Cretácico superior y una capa de roca sobreyacente de conglomerados y arenas de playa, cartografiada por Gastil et al. (1971) como formación Cantil Costero del Plioceno (Fig. 2a). Un escarpe paralelo menor que expone la misma discordancia se presenta $3 \mathrm{~km}$ tierra adentro.

La formación Rosario fue nombrada y descrita por Beal (1948). De acuerdo con el sumario elaborado por Silver et al. (1963), la edad de ésta es Campaniano-Maestrichtiano. La composición bajo la discordancia con estratos más recientes es variable de lugar a lugar a to largo de la costa del Pacífico. Al norte, cerca de Eréndira, presenta lutita (Lescinsky et al., 1991). El área de Camalú-Colonet tiene conglomerados y areniscas (Miller y Abbott, 1989). Al sur de El Rosario, donde la formación completa es de hasta $380 \mathrm{~m}$ de grosor, se encuentran depósitos terrígenos con restos de plantas (Kilmer, 1963). En el área del proyecto, la litología prevaleciente consiste en limolita másiva del Cretácico con un contenido de carbonato de aproximadamente $35 \%$. El área de estudio fue escogida por la suavidad, comparativamente hablando, de esta litologia y por la discontinuidad local Cretácico-Plioceno.

La formación Cantil Costero fue descrita por Santillán y Barrera (1930). El nombre se justifica por el prominente escarpe local. Cerca de la costa, la formación tiene típicamente de 10 a $12 \mathrm{~m}$ de grosor y consiste en conglomerados basales que yacen sobre arenas de playa de grano fino. Los conglomerados incluyen clastos derivados de rocas del basamento local, igneas y estratos más recientes, inmediatamente al este (Gastil et al., 1975). Son clementos conspicuos grandes restos retrabajados de Tamiosoma gregaria Conrad, 1856 (Zullo, 1992), de un intervalo geológico desde el Plioceno hasta nuestros días, que pertenecen a la facies de arena de playa. Finalmente, Zullo (1992), basado en la presencia de Tamiosoma gregaria en el norte de Baja California, fecha la formación Cantil 
on the front of the escarpment (A-D) and two additional stations located $3 \mathrm{~km}$ inland from the main escarpment ( $E$ and $F$ ) were investigated to better understand the physical nature of the disconformity and the density of biological activity (trace fossils) on the disconformity surface. Stations $\mathrm{E}$ and $\mathrm{F}$ were studied to determine the variation perpendicular to the shoreline. Stratigraphic relationships above the disconformity were recorded at all stations. These include the thickness of basal conglomerates in contrast to the overall thickness of the Pliocene strata, the thickness of smaller subunits distinguished by graded bedding within the basal conglomerates, and the maximum clast sizes within individual graded beds (as determined by a sampling of the five largest clasts at any given horizon). The fossil remains of clast-encrusting organisms were also searched for within the Pliocene conglomerates.

The final phase of the field work involved the examination of the nearby Pacific coastline, where an active intertidal abrasion platform is incised in similar thick Cretaceous siltstones. This part of the study was conducted to determine which geomorphic features of comparable scale link the modern and Late Pliocene environments. Through this comparison we hope to resolve the issues concerning the mode of origin of the elevated disconformity surface.

\section{RESULTS}

The results of this study are summarized in table 1. Stratigraphic relationships parallel to the paleo-shoreline from stations $\mathrm{A}$ to $\mathrm{D}$ (Fig. 1) are very consistent. There are no obvious intraformational breaks within the Rosario Formation. The overall thickness of the Cantil Costero Formation maintains close to an average of nearly $11 \mathrm{~m}$. The basal conglomerates generally account for a quarter of the thickness (table 1). Abundant borings diagnostic of the ichnospecies Gastrochaenolites ornatus (Kelly and Bromley, 1984) penetrate the abrasion platform to a depth of up to $10 \mathrm{~cm}$ (Fig. 2c), although their density varies widely. Many of these borings retain the shells of the pholadid bivalve Penitella penita (Conrad, 1837). The maximum density of preserved borings is ap-
Costero como del Plioceno, y no de la edad pleistocénica, como previamente había determinado Valentine (1955).

\section{METODO DE ESTUDIO}

Seis afloramientos fueron examinados (en las estaciones designadas A a F), como se muestra en la Fig. 1. Para entender mejor la naturalcza física de la discordancia y la densidad de la actividad biológica (icnofósiles) en su superficie, se investigaron cuatro estaciones en el frente del escarpe (A a D) y dos estaciones adicionales localizadas $3 \mathrm{~km}$ tierra adentro, desde el escarpe principal (E y F). Se estudiaron las estaciones $\mathrm{E}$ y $\mathrm{F}$ para determinar la variación perpendicular hacia la costa. Las relaciones estratigráficas sobre la discordancia fueron también registradas. Estas incluyen el grosor de los conglomerados basales en contraste con el grosor total del Plioceno, el grosor de las subunidades menores distinguidas por la gradación dentro de los conglomerados basales y los tamaños de clasto máximos dentro de los estratos gradados individuales (determinados por el muestreo de los cinco mayores clastos en cualquier horizonte dado). Dentro de los conglomerados pliocénicos, se recogieron también restos fósiles de organismos epilíticos.

La fase final del trabajo de campo incluyó el examen de la costa cercana del Pacífico, donde una plataforma de abrasión intermareal activa se inserta en la misma potente lutita cretácica. Esta parte del estudio se orientó a determinar qué características geomórficas de escala comparable unen los ambientes modernos con los del Plioceno tardío.

Con esta comparación, esperamos resolver los puntos relativos a la forma en que se originó la superficie de la elevada discordancia.

\section{RESULTADOS}

Los resultados de este estudio se resumen en la tabla 1. Las relaciones estratigráficas a lo largo de las estaciones A a D (Fig. 1) son muy consistentes. No hay variaciones intraformacionales obvias dentro de la formación Rosario. La potencia total promedio de la formación Cantil Costero se aproxima a casi $11 \mathrm{~m}$. Los 
Table 1. Stratigraphic and paleontological tabulations from the Pliocene Cantil Costero Formation near El Rosario, Baja California, Mexico (localities in Fig. 1).

Tabla 1. Tabulaciones estratigráficas y paleontológicas de la formación Cantil Costero del Plioceno, al norte de El Rosario, Baja California, México (localidades en la Fig. 1).

\begin{tabular}{lcccccc}
\hline & $\mathrm{A}$ & $\mathrm{B}$ & $\mathrm{C}$ & $\mathrm{D}$ & $\mathrm{E}$ & $\mathrm{F}$ \\
\hline $\begin{array}{c}\text { Overall thickness of } \\
\text { Pliocene (m) }\end{array}$ & 11.0 & 11.6 & 10 & 11 & 6.0 & 5.5 \\
$\begin{array}{c}\text { Thickness of wave-worked } \\
\text { conglomerate (m) }\end{array}$ & 2.10 & 2.50 & 2.60 & 3.90 & 1.80 & 1.90 \\
$\begin{array}{c}\text { Sedimentary structures } \\
\text { present }\end{array}$ & $\begin{array}{c}\text { graded } \\
\text { beds }\end{array}$ & $\begin{array}{c}\text { graded } \\
\text { beds }\end{array}$ & $\begin{array}{c}\text { dissecting } \\
\text { arroyo }\end{array}$ & $\begin{array}{c}\text { graded } \\
\text { beds }\end{array}$ & $\begin{array}{c}\text { dissecting } \\
\text { arroyo }\end{array}$ & $\begin{array}{c}\text { laminated } \\
\text { sandstone }\end{array}$ \\
$\begin{array}{c}\text { Average thickness of } \\
\text { graded beds (m) }\end{array}$ & 1.20 & 0.50 & 0.30 & 0.35 & 0.25 & 0.20 \\
$\begin{array}{c}\text { Average maximum clast } \\
\text { size of basal units in } \\
\text { graded beds (m) }\end{array}$ & 0.08 & 0.05 & 0.09 & 0.10 & 0.04 & 0.04 \\
$\begin{array}{c}\text { Average maximum size } \\
\text { of terminal units } \\
\text { (graded beds) (m) }\end{array}$ & 0.40 & 0.30 & 0.20 & 0.30 & 0.15 & 0.15 \\
$\begin{array}{c}\text { Clast-encrusting fauna } \\
\text { present }\end{array}$ & barnacles & - & barnacles & barnacles & barnacles & barnacles \\
$\begin{array}{c}\text { Density of pholadid } \\
\text { borings in 0.25 } \mathrm{m}^{2}\end{array}$ & 125.00 & 35.00 & 15.00 & 25.00 & 0.00 & 0.00 \\
\hline
\end{tabular}

Figure 2. Details of the Pliocene-Cretaceous disconformity in bluffs north of El Rosario on the Pacific coast of Baja California, Mexico. a) View looking east from kilometer marker 40 midway between stations C and D (see Figs. 1 and 3) on Mexican Federal Highway 1, with Agave plants $3 \mathrm{~m}$ high in the foreground; background shows steep slope of Upper Cretaceous siltstone (Rosario Formation) overlain by $4 \mathrm{~m}$ of basal Pliocene conglomerate (Cantil Costero Formation). b) View at top of escarpment showing graded beds within the Pliocene conglomerate overhanging recessed Cretaceous siltstone. Note downward-concave form of conglomerates draping the disconformity surface. c) Close-up view of Pliocene pholadid bivalve borings exhumed from below the disconformity surface; these borings penetrate the Cretaceous siltstone to a depth of up to $10 \mathrm{~cm}$. d) View looking upward at the basal contact of the Pliocene; the density of pholadid borings is about $200 / \mathrm{m}^{2}$.

Figura 2. Detalles de la discordancia Cretácico-Plioceno en acantilados al norte de El Rosario, en la costa del Pacífico de Baja California, México. a) Vista de la parte este, desde la marca de los $40 \mathrm{~km}$, a medio camino entre las estaciones C y D (véase Figs. 1 y 3), en la carretera federal 1. con plantas de agave de $3 \mathrm{~m}$ de altura en el frente; en la parte posterior se muestra el declive pronunciado de las lutitas del Cretácico superior (formación Rosario) cubiertas por $4 \mathrm{~m}$ de conglomerados basales del Plioceno (formación Cantil Costero). b) Vista desde la parte superior del escarpe, donde se muestran los estratos gradados dentro del conglomerado del Plioceno sobreyacente en las lutitas Cretácicas. Nótese la forma cóncava hacia abajo de los conglomerados que yacen sobre la superficie de la discontinuidad. c) Detalle de las perforaciones de bivalvos foládidos del Plioceno expuestas bajo la superficie de la discontinuidad; estas perforaciones penetran en la lutita del Cretácico a una profundidad de hasta $10 \mathrm{~cm}$. d) Vista desde la parte superior del contacto basal del Plioceno; la densidad de perforaciones de foládidos es de alrededor de $200 / \mathrm{m}^{2}$. 
Ledesma-Vázquez and Johnson: Late Pliocene abrasion platform from the Cantil Costero Formation
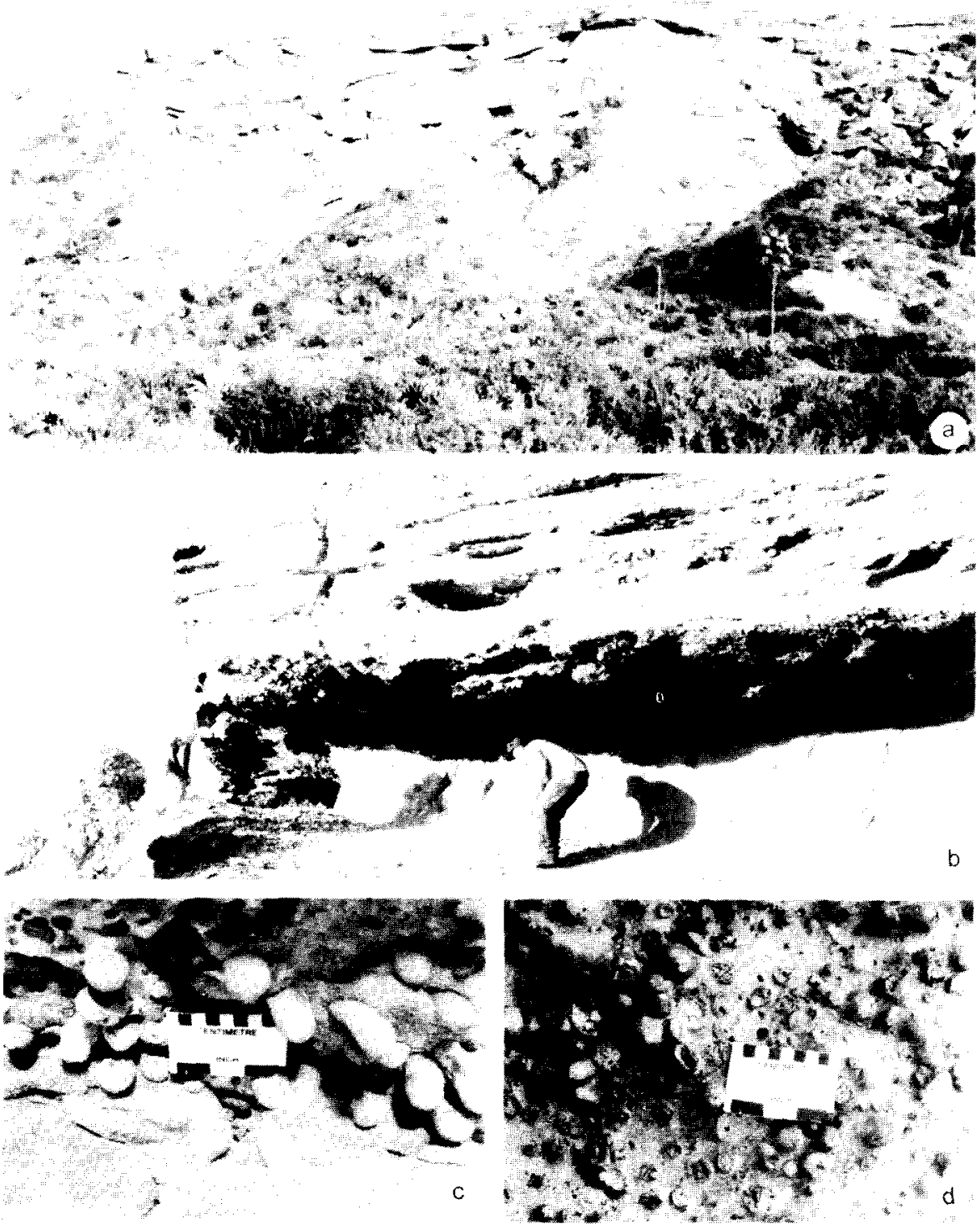


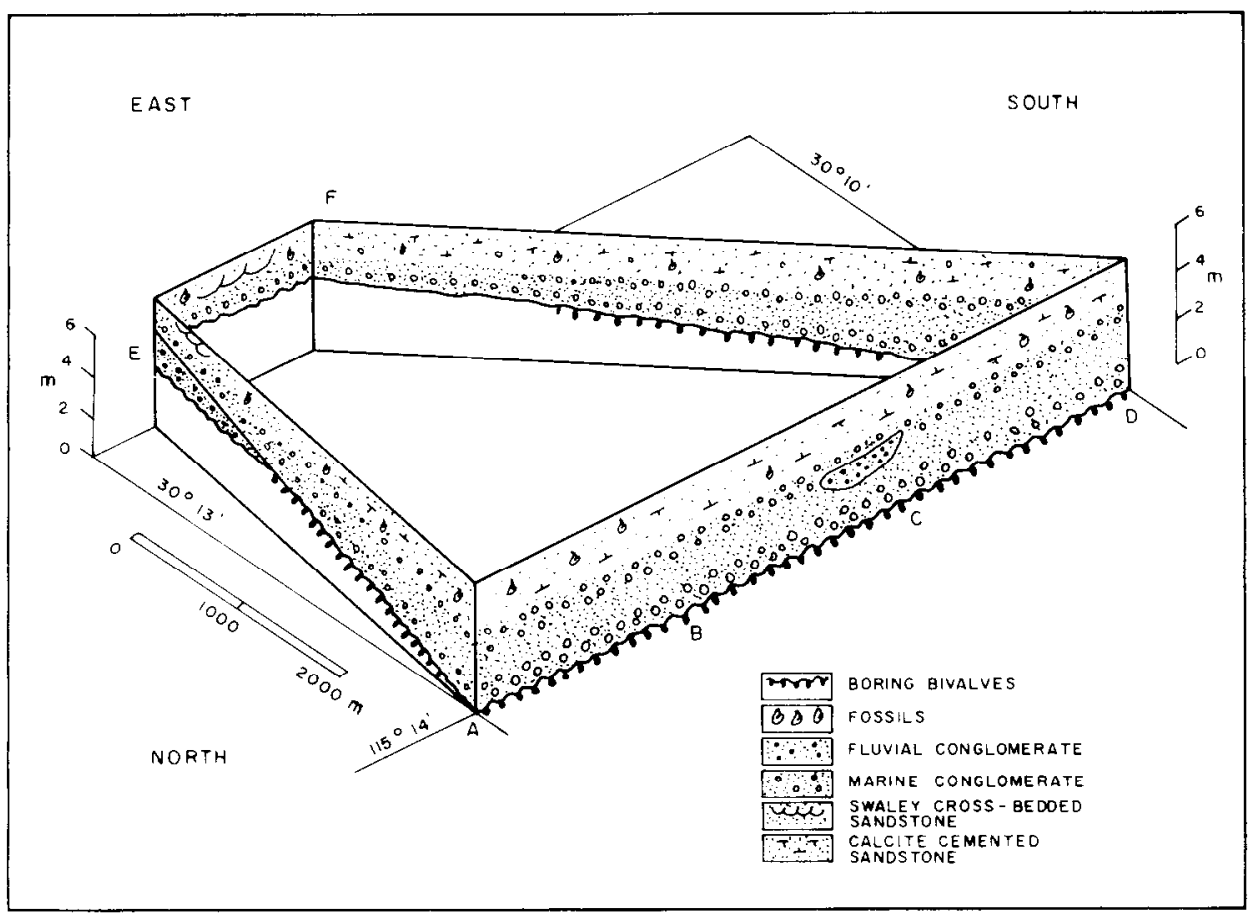

Figure 3. Fence diagram, showing wedge of Pliocene conglomerates and initial beach sands belonging to the Cantil Costero Formation, which sit unconformably on siltstones belonging to the Upper Cretaceous Rosario Formation. Columns A to F correspond to stratigraphic sections measured at stations A to F (Fig. 1). Pholadid bivalve borings extend continuously from stations A to D, but only part way to stations $\mathrm{E}$ and $\mathrm{F}$ where the Pliocene cover is thinner.

Figura 3. Diagrama de bloque que muestra la cuña de conglomerados del Plioceno y arenas iniciales de playa pertenecientes a la formación Cantil Costero, la cual se asienta en discordancia sobre las lutitas de la formación Rosario del Cretácico superior. Las columnas A a F corresponden a las secciones estratigráficas medidas en las estaciones A a F (Fig. 1). Las perforaciones de bivalvos foládidos están presentes de una manera continua desde la estación $\mathrm{A}$ a la $\mathrm{D}$, pero sólo en parte del trayecto entre las estaciones E y F, donde la cohertura pliocénica es más delgada.

proximately $200 / \mathrm{m}^{2}$ (Fig. 2d), observed midway between stations $\mathrm{C}$ and $\mathrm{D}$ (Fig. 1 ).

At stations $E$ and $F$ (Fig. 1), the stratigraphic section also is consistent along a north-south axis. IIere. the basal conglomerates account for about one third of the overall thickness of the Pliocene section, but thicknesses are notably different from trends to the west. The overall thickness of the Pliocene section is reduced to half the average thickness for stations $A-D$, whereas the thickness of the basal conglomerates is reduced to about two thirds of the average thickness for stations $A$-D (table 1). conglomerados basales generalmente presentan un cuarto de ese grosor (tabla 1). Una abundancia de perforaciones típicas de la icnoespecie Gastrochaenolites ornatus (Kelly y Bromley, 1984) penetran la plataforma de abrasión, a una profundidad de hasta $10 \mathrm{~cm}$ (Fig. 2c), aun cuando su densidad varia ampliamente. Muchas de las perforaciones conservan las conchas del bivalvo foládido Penitella penita (Conrad, 1837). La densidad máxima de las perforaciones preservadas es de aproximadamente $200 / \mathrm{m}^{2}$ (Fig. 2d), y se observó a medio camino entre las estaciones $C$ y D (Fig. 1). 
Pholadid borings are absent from the abrasion platform at stations $\mathrm{E}$ and $\mathrm{F}$. The conglomerate unit covering the disconformity surface is distinctly wedge-shaped, thickening seaward (west) and thinning landward (east). This is confirmed by the contrasting views of the different escarpments illustrated in Figs. 2a, $b$ (west) and Figs. 4a, b (east). A fence diagram (Fig. 3) summarizes the stratigraphic relationships among stations $A$ to $F$.

Despite stratigraphic variation affecting the shape of the conglomeratic platform cover, other data indicate that depositional conditions were relatively uniform within this deposit. With few exceptions, the average thickness of successive graded beds is fairly consistent. So too is the average maximum size of clasts examined at the base and top of individual beds (table 1). Variation in the thickness of graded beds may be attributed to localized amalgamation. Cobble-encrusting barnacles of the Balanus amphitrite complex (V.A. Zullo, 1992, personal communication) were found at all but one station (Fig. 4c), indicating the prevalence of shallow marine conditions.

An unexpected feature found dissecting the Pliocene-Cretaceous disconformity surface is the occurrence of filled arroyo channels. Fluvial conglomerates entrenched in the Rosario Formation are observed at stations $\mathrm{C}$ and $\mathrm{E}$ (table 1). As marked in Fig. 3, they indicate that fluvial channels cut across the full width of the disconformity.

Although not recorded at any of the stations in table 1, runnel-like features commonly occur in cross section as downward-concave structures in the conglomerates draping the disconformity, and as linear trough fillings exposed in the overhanging roof (Fig. 2b). These troughs are in the proper orientation to have been produced by tidal action. A landward view looking up the valley of Arroyo Hondo is shown in Fig. 5a. The photograph was taken at low tide, and the dark irregular surface in the foreground is the active, modern-day abrasion platform cut across the Rosario Formation. Tide croded runnels perpendicular to the shoreline are visible in the siltstone substrate. The platform is free of debris except for a few loose cobbles. At a higher elevation in the back-
En las estaciones E y F (Fig. 1), la sección estratigráfica también es consistente a lo largo de un eje norte-sur. Aquí, los conglomerados basales presentan un tercio del espesor total de la sección del Plioceno, pero los grosores son notablemente diferentes hacia el oeste. El grosor total de la sección del Plioceno está reducido a la mitad del grosor promedio de las estaciones $\mathrm{A}$ a $\mathrm{D}$, mientras que el grosor de los conglomerados basales está reducido aproximadamente a dos tercios del grosor promedio en las estaciones A a D (tabla 1). En las estaciones E y $\mathbf{F}$ de la plataforma de abrasión, no se presentan perforaciones de foládidos. La unidad de conglomerados que cubre la superficie de discordancia tiene forma de cuña, que engrosa hacia el mar (oeste) y adelgaza hacia tierra adentro (este). Esto es confirmado por las vistas contrastantes de los diferentes escarpes ilustrados en las Figs. $2 \mathrm{a}$ y b (oeste) y $4 \mathrm{a}$ y $\mathrm{b}$ (este). Un diagrama de bloque (Fig. 3) resume las relaciones estratigráficas entre todas las estaciones.

A pesar de la variación estratigráfica que afecta la forma de la cubierta de la plataforma conglomerática, otros datos indican que las condiciones depositacionales fueron relativamente uniformes en este depósito. Con algunas excepciones, el grosor promedio de las capas gradadas sucesivas es bastante consistente. Igualmente consistente es el tamaño máximo promedio de los clastos examinados en la base y en la parte superior de cada estrato individual (tabla 1). La variación en el grosor de estratos gradados puede atribuirse a amalgamación local. Se encontraron balanos del complejo $\mathrm{Ba}$ lanus amphitrite (V.A. Zullo, 1992, comunicación personal) en todas las estaciones excepto una (Fig. 4c), lo que indica predominio de condiciones de mar somero.

Una característica inesperada que se encontró inspeccionando la superficie de contacto Cretácico-Plioceno fue la presencia de canales de arroyos. En las estaciones $C$ y $E$, se observaron conglomerados fluviales atrincherados en la formación Rosario (tabla 1). Como se marcó en la Fig. 3, éstos indican que canales fluviales cortan la discordancia a todo lo ancho.

Aunque no se grabaron en ninguna de las estaciones de la tabla 1 , se encontraron marcas 

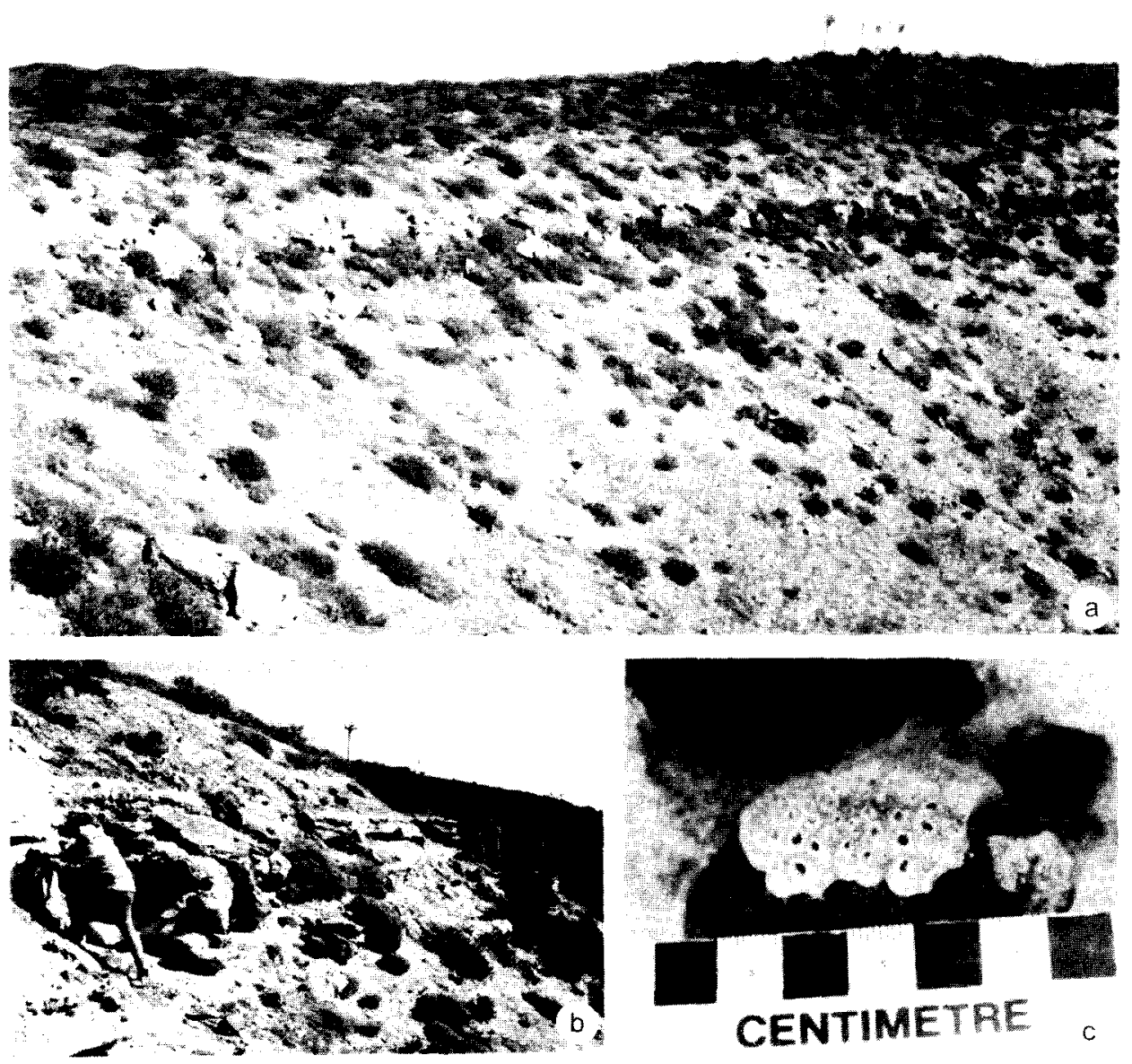

Figure 4. Details of the Pliocene-Cretaceous disconformity exposed in more inland bluffs at stations $\mathrm{E}$ and $\mathrm{F}$ (see Figs. 1 and 3 ). a) General view showing the resistant line of basal Pliocene conglomerate and sandstone only $1.8 \mathrm{~m}$ thick at station $E$, compared to a maximum of $4.0 \mathrm{~m}$ in coastal bluffs to the west (Agave plants on horizon for scale). b) View of Pliocene conglomerates and laminated sandstone $1.9 \mathrm{~m}$ thick at station F. c) Close-up view of igneous cobble from the basal Pliocene conglomerate encrusted with barnacles (Balanus) at station E.

Figura 4. Detalles de la discordancia Cretácico-Plioceno expuesta en acantilados más tierra dentro en las estaciones E y F (véase Figs. 1 y 3). a) Vista general de lá resistente línea de conglomerados basales del Plioceno y areniscas de únicamente $1.8 \mathrm{~m}$ de groso: en la estación $\mathrm{E}$, comparada con el máximo de $4.0 \mathrm{~m}$ en los acantilados costeros al oeste (las plantas de agave en el horizonte pueden tomarse como escala). b) Vista de los conglomerados pliocénicos y arenisca laminada de $1.9 \mathrm{~m}$ de grosor en la estación F. c) Acercamiento de cantos rodados de origen ígneo del conglomerado basal del Plioceno, recubiertos por balanos (Balanus), en la estación E. 

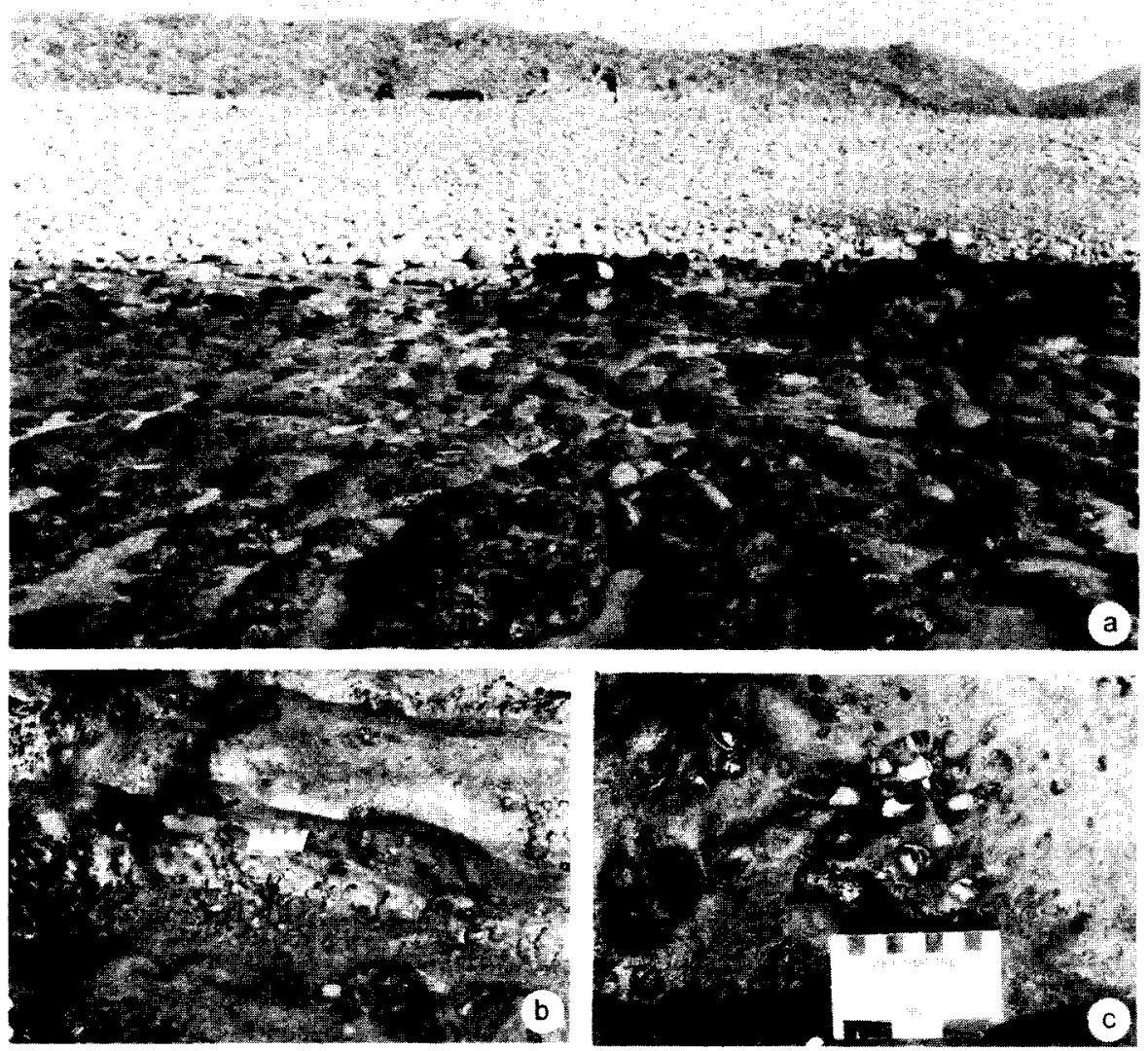

Figure 5. Details of modern, intertidal abrasion platform eroded in Upper Cretaceous siltstones (Rosario Formation) on the shores of the Pacific Ocean. a) Landward view from the intertidal zone (low tide) at the mouth of Arroyo Hondo with encroaching berm of loose cobbles below kilometer marker 35 on Mexican Federal Highway 1 (see Fig. 1); note spacing of runnels perpendicular to the shore. b) Side view of runnels with abundant borings of pholadid bivalves. c) Close-up view of pholadid bivalves.

Figura 5. Detalles de la plataforma de abrasión intermareal moderna en lutitas del Cretácico superior (formación Rosario) en las costas del océano Pacífico. a) Vista hacia tierra desde la zona intermareal (marea baja) en la boca de arroyo Hondo con cantos rodados sueltos que invaden la berma abajo de la marca del km 35 de la carretera federal mexicana 1 (véase Fig. 1). Nótese el espaciamiento de los canales perpendiculares a la playa. b) Vista de lado de los canales con abundantes perforaciones de bivalvos foládidos. c) Acercamiento de los bivalvos foládidos.

ground is a cobble beach, which is washed by high tides. The cobbles are primarily igneous in origin, and they were transported to the shore by way of Arroyo Hondo. A closer view looking across the runnels is shown in Fig. 5b, with the detail of recent pholadid bivalves shown in Fig. 5c. tipo arroyo labradas comúnmente en sección cruzada, como estructuras cóncavas hacia abajo en los conglomerados que descansan sobre la discordancia y como rellenos de canales lineales expuestos en el techo superior (Fig. 2b). Estos canales tienen la orientación propia de haber sido producidos por mareas. Una vista 


\section{DISCUSSION}

This section reviews supporting evidence for our interpretation of the various stages of development undergone by the local coastline, as well as more global questions concerning comparisons with disconformities of other ages, such as the Cretaceous examples referred to in the introduction. The Late Pliocene coastline north of El Rosario underwent at least three discrete stages of development, involving the landward abrasion of a platform along a continuous $6 \mathrm{~km}$ stretch, its local inundation by land-derived clasts, and its subsequent accommodation of clasts through on-going progradation. We believe all three stages took place under intertidal to shallow subtidal conditions and that the Pliocene-Cretaceous disconformity is, therefore, an example of an abrasion platform at this interfacc. A combination of both biological and physical evidence supports these interpretations.

\section{Development by boring bivalves}

Boring bivalves, including those commonly present along the shores of Baja California, use both mechanical and chemical methods to excavate their holes. The conditions under which such bivalves thrive were recently reviewed by Fischer (1990). Chemical activity is used by some bivalves boring into substrates made of limestone, marl or even shale with a minor concentration of calcium carbonate. Purely mechanical excavation may occur in a wider variety of sedimentary rocks, but occurs less often in metamorphic and igneous substrates. According to Fischer (1990), one of the most important inducements for the colonization of boring bivalves is the presence of active water conditions providing a clean, sediment-free substrate. Literature concerning the depth at which loose sand may scour a submarine rock surface was recently reviewed by Trenhaile (1987), with the conclusion that maximum activity occurs to a depth of $9-10 \mathrm{~m}$. "It is generally belicved that submarine erosion is much slower than erosion in the intertidal zone, where water hammer, hydraulic quarrying, and abra- hacia tierra adentro del valle de arroyo Hondo se muestra en la Fig. 5a. La fotografia fue tomada durante la bajamar y la superficie irregular obscura en el frente es la plataforma de abrasión activa que corta la formación Rosario. Los canales producidos por las mareas, perpendiculares a la linea de costa, son visibles en el sustrato de lutitas. La plataforma está libre de material suelto, excepto por algunos clastos. Un poco más arriba, en el fondo, hay una playa de clastos que se lava durante las mareas altas. Los clastos son principalmente de origen ígneo y fueron transportados a la costa a través de arroyo Hondo. Una vista más cercana de los canales se muestra en la Fig. 5b, junto con el detalle de bivalvos foládidos recientes, en la Fig. 5c.

\section{DISCUSION}

Esta sección analiza la evidencia que apoya nuestra interpretación de los varios estadios de desarrollo sufridos por la costa local, así como preguntas de mayor escala regional concernientes a comparaciones con discordancias de otras épocas, tales como los ejemplos del Cretácico referidos en la introducción. En la línea de costa al norte de El Rosario, durante el Plioceno tardío, se presentaron por lo menos tres estadios discretos de desarrollo, que involucraron la abrasión hacia tierra adentro de una plataforma a lo largo de un tramo continuo de $6 \mathrm{~km}$, su inundación local por clastos provenientes de tierra adentro y el acomodo subsecuente de los clastos a través de una progradación sucesiva. Creemos que los tres estadios tuvieron lugar bajo condiciones intermareales a submareales someras y que la discordancia Cretácico-Plioceno es un ejemplo de plataforma de abrasión en esta interfase. Una combinación de evidencia tanto física como biológica apoya estas interpretaciones.

\section{Desarrollo por bivalvos perforadores}

Los bivalvos perforadores, incluyendo aquéllos presentes comúnmente a lo largo de las costas de Baja California, usan métodos tanto químicos como físicos para excavar sus túneles. Las condiciones bajo las cuales tales bivalvos se desarrollan fueron recientemente 
sion operate either exclusively or most efficiently" (Trenhaile, 1987, p. 238). Efficiency in the abrasion of the Pliocene platform is strongly suggested by its lateral persistence and the fact that the substrate was initially kept clean for extensive pholadid colonization.

\section{Development of basal conglomerate}

Emplacement of platform conglomerates indicates the second stage in the development of the local Pliocene shoreline. This was essentially a progradational phase, with clastic material derived from a land source to the east comprised of older sedimentary rocks and igneous basement rocks (Gastil et al., 1975). Tectonic uplift, at a rate of $1 \mathrm{~mm} / \mathrm{yr}$ in the Sierra San Pedro Mártir farther to the east, is considered to have begun about 2 m.y. ago (Dorsey, 1991). Localized extermination of pholadid populations suggests that uplift continued from an abrupt start. Small pebbles typically choke the entrance to the borings across the entire seaward platform.

As described in a study of Pliocene strata on King George Island, Antarctica (Gazdzicki et al., 1982), a similar fate was met by Penitella sp. and other associated pholadids that apparently were buried by sudden gravity flows of pebbly sandstone. Recolonizations of mudstone substrates took place, but they were interrupted repeatedly by a succession of gravity flows. In contrast, once Late Pliocene uplift began in this region of Baja California, the local near-shore recolonization of Penitella penita was blocked for the duration. Physical evidence, including the repetition of graded conglomerate beds, and biological evidence, including widespread clast encrustation by barnacles, indicate that progradation was strongly affected by intertidal conditions.

The wedge shape of the platform conglomerate (Fig. 3) reflects a third stage in development. The platform cover thins in the landward direction, suggesting full post-tectonic accommodation of land-derived clastics in the coastal zone. The area was initially overwhelmed by a broad front of material delivered by fluvial processes, but vigorous sorting in the intertidal zone appears to have moved the bulk of this material seaward well after tectonic-driven supply ceased. examinadas, en detalle, por Fischer (1990). La actividad química se asocia con bivalvos perforadores en substratos compuestos por calizas, margas $o$ incluso pizarras con una concentración mínima de carbonato de calcio. La excavación puramente mecánica se puede presentar en una variedad más amplia de rocas sedimentarias pero con menos frecuencia en substratos metamórficos e ígneos. Según Fischer (1990), una de las condiciones inductivas más importantes para la colonización de bivalvos perforadores es la presencia de agua en movimiento que provea un substrato limpio, libre de sedimento suelto. La literatura sobre la profundidad a la cual la arena suelta puede moverse en una superficie rocosa submarina fue recientemente examinada por Trenhaile (1987), quien concluye que la actividad máxima ocurre a una profundidad de 9 a $10 \mathrm{~m}$. "Generalmente se cree que la erosión submarina es mucho más lenta que la erosión en la zona intermareal, donde la ruptura del oleaje, el arranque hidráulico y la abrasión operan en exclusividad o más eficientemente" (Trenhail, 1987, p. 238). La eficiencia en la abrasión de la plataforma del Plioceno es sugerida fuertemente por su persistencia lateral y el hecho de que el substrato se mantuvo limpio inicialmente, para la colonización extensiva por foládidos.

\section{Desarrollo del conglomerado basal}

El emplazamiento de la plataforma de conglomerados indica el segundo estadio en el desarrollo local de la línea de costa del Plioceno. Esta fue esencialmente una fase progradante, con materiales clásticos derivados de una fuente terrestre al este, compuesta de rocas sedimentarias más antiguas y rocas ígneas del basamento (Gastil et al., 1975). El levantamiento tectóni-

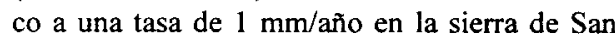
Pedro Mártir, más hacia el este, se considera que comenzó aproximadamente hace 2 m.a. (Doresey, 1991). El exterminio localizado de poblaciones de foládidos sugiere un levantamiento continuo después de un comienzo abrupto. La entrada de las perforaciones está típicamente obstruida por grava, a través de toda la plataforma que da hacia el mar.

Como se describió en un estudio de estratos del Plioceno de la isla King George, en la Antártida (Gazdzicki et al., 1982), un destino 


\section{Development of paleo-arroyos}

The most unique piece of evidence indicating the proximity to land of the Cretaceous-Pliocene disconformity is the occurrence of Pliocene paleo-arroyos entrenched in the Cretaceous substrate (Fig. 3). Runnel-like features preserved elsewhere on the same surface reinforce the interpretation that Plincene arroyos intersected the intertidal zone. Runnels of comparable shape and size are preserved on a Jurassic-age abrasion platform in southern Wales (Fletcher, 1988). In the study areas, recent arroyos filled with fluvial conglomerates, such as Arroyo Hondo (Fig. 1), work their way to the local Pacific shoreline, but they are deeply incised through at least $84 \mathrm{~m}$ of the Rosario Formation (as measured from main escarpment $1 \mathrm{~km}$ inland). The paleo-arroyos are incised only a few meters into the Cretaceous disconformity surface; they represent the leading tongues of a far more massive and regionally uniform progradation of Pliocene clastics. A similar phenomenon concerns inlets called calanques, which are related to the mouths of entrenched streams in coastal karst topography (Trenhaile, 1987, p. 264).

\section{Contrast with other disconformities}

No sea cliffs are associated with the Pliocene-Cretaceous disconformity preserved near El Rosario. This was determined by tracing the surface perpendicular to the paleo-coastline along exposures eroded by Arroyo Hondo between stations $A$ and $E$ (Fig. 1). It is in this sense that the two escarpments running through stations A-D and E-F cannot be considered separate terraces. Unconformities with such low relief are commonly difficult to interpret, with conflicting claims possible for submarine as opposed to intertidal and subacrial origins (see Johnson. 1992).

The disconformities in the Cretaceous limestones of Texas are typical in this regard. Submarme formation is favored by Rose (1970). but intertidal abrasion platforms are favored in at least one case by Lewy (1985). In his resiarch on similar disconformities in the (retaceous of Lracl. Lewy (1985) was able to similar se consideró para Penitella sp. y otros foládidos asociados que aparentemente fueron enterrados por flujos de gravedad súbitos de arenisca con gravas. Hubo recolonizaciones de los substratos de limolita, pero fueron interrumpidas repetidamente por una sucesión de flujos de gravedad. En contraste, una vez que el levantamiento del Plioceno tardío comenzó en esta región de Baja California, la recolonización local de Penitella penita cerca de la costa fue bloqueada por la duración del evento. La evidencia física, que incluye la repetición de estratos de conglomerados gradados. y la evidencia biológica, que incluye la incrustación de balanos en clastos sobre toda la superficie, indican que la progradación fue fuertemente afectada por condiciones intermareales.

La forma acuñada de la plataforma de conglomerados (Fig. 3) refleja una tercer estadio de desarrollo. La cubierta de la plataforma se adelgaza hacia tierra adentro, sugiriendo un acomodo postectónico completo de clastos terrígenos en la zona costera. El área fue inicialmente recubierta por un amplio frente de material derivado de procesos fluviales, pero una separación vigorosa en la zona intermareal parece haber movido la mayor parte de este material hacia el mar, después de que el aporte producido por el régimen tectónico cesó.

\section{Desarrollo de paleoarroyos}

La única pieza de evidencia que indica la proximidad de la discordancia con la tierra es la presencia de paleoarroyos excavados en el substrato cretácico (Fig. 3). Las marcas tipo arroyo preservadas en toda la superficie refuerzan la interpretación de que los arroyos del Plioceno se entrecruzaron en la zona intermareal. Arroyos de forma y tamaño comparable se encuentran preservados en una plataforma de abrasión jurásica en el sur de Gales (Fletcher, 1988). Arroyos recientes llenos con conglomerados fluviales, tales como arroyo Hondo (Fig. 1), aún continúan acarreando material a la costa local del Pacífico. Pero han cavado profundamente en la formación Rosario hasta $84 \mathrm{~m}$ (según lo medido desde el escarpe principal. I km tierra adentro). Los paleoarroyos están excavados únicamente unos cuantos metros dentro de la superficie de discordancia del 
support the interpretation of intermittent exposure and burial of rockgrounds in an intertidal setting through the occurrence of lateral conglomerates and mudcracks. This kind of supporting evidence is not available in the Cretaceous of Texas, but intertidal abrasion may have lowered the platform surface to the extent where borings nearly vanished. Preservation of karst features with more relief on any scale up to and including calanques may be necessary to prove a former period of subaerial exposure and coastal erosion.

\section{Rate of coastal erosion}

In a compilation of modern erosion rates on coastal cliffs, Sunamura (1992, pp. 265-277) lists observations on a dozen Pliocene mudstones and siltstones, mostly from the coast of Japan. Rates of erosion vary between 0.13 to $2.05 \mathrm{~m} / \mathrm{yr}$ under present-day conditions. On average, however, the rate of intertidal erosion for such a soft lithology is $0.90 \mathrm{~m} / \mathrm{yr}$. Assuming similar intertidal conditions during the Pliocene erosion of siltstones belonging to the Cretaceous Rosario Formation, the platform on which the Cantil Costero Formation sits may have been abraded $3 \mathrm{~km}$ landward in as little as 3,000 years. No trace of a siltstone sea cliff was left remaining after this transgression.

\section{CONCLUSIONS}

Intertidal abrasion platforms not backed by sea cliffs constitute a special category of rocky shores. The following conclusions summarize the physical attributes of the abrasion platform and platform cover comprised of the Upper Pliocene Cantil Costero Formation near El Rosario, Baja California.

1. The abrasion platform occurs at a single disconformity between Upper Pliocene conglomerates and Upper Cretaceous siltstones; no other intro-formational hardgrounds or omission surfaces occur at lower stratigraphic levels in the thick Cretaceous siltstones.

2. Lateral extent parallel to the Pliocene paleo-coastline is more than $6 \mathrm{~km}$, with a width of at least $3 \mathrm{~km}$. The single disconformity surface covers more than $18 \mathrm{~km}^{2}$ and it formed under intertidal to shallow subtidal conditions.
Cretácico; éstos representan las lenguas apicales de una progradación más másiva e incluso regional de clastos pliocénicos. Un fenómeno similar concierne a los canales de acceso llamados calanques, los cuales están relacionados con las bocas de ríos encanalados en topografía cárstica costera (Trenhail, 1987, p. 264).

\section{Contraste con otras discordancias}

No hay cantiles marinos asociados con la discordancia Cretácico-Plioceno preservada cerca de El Rosario. Esto se determinó trazando la superficie perpendicular a la palenlínea de costa a lo largo de los afloramientos erosionados por el arroyo Hondo entre las estaciones A y E (Fig. 1). Fn este sentido, los dos escarpes que corren a través de las estaciones $A$ a $D$ y $E$ a $F$ no se pueden considerar terrazas separadas. Las discordancias con relieve tan bajo frecuentemente son difíciles de interpretar, ya que igual puede plantearse que son de origen submarino que, por el contrario, intermareal y subaéreo (Johnson, 1992).

Las discordancias en las lutitas cretácicas de Texas son típicas desde este punto de vista. El origen submarino es apoyado por Rose (1970), pero las plataformas de abrasión intermareales son defendidas, por lo menos en un caso, por Lewy (1985). En su investigación sobre discordancias similares en el Cretácico de Israel, Lewy (1985) pudo apoyar la interpretación de exposición intermitente y enterramiento de superficies rocosas en un emplazamiento intermareal a través de la presencia de conglomerados laterales y fracturas por desecamiento en limos. Este tipo de evidencia de apoyo no se encuentra en el Cretácico de Texas, pero la abrasión intermareal pudo erosionar la superficie de la plataforma a tal grado que las perforaciones casi desaparecieron. La preservación de características cársticas con más relieve en cualquier escala hasta la de calanques, puede ser necesaria para probar un periodo antecedente de exposición subaćrea y erosión costera.

\section{Tasa de erosión costera}

En una recopilación de las tasas de erosión modernas en los cantiles costeros, Sunamura 
3. During the active abrasion phase of the platform, it was kept clear of detritus and the siltstone surface was extensively colonized by immense populations of boring pholadid bivalves along its entire coastal length. Population density varied, but maximum density was about $200 / \mathrm{m}^{2}$. Many of the bivalves belonging to Pentella penita are still intact within borings, which are up to $10 \mathrm{~cm}$ deep.

4. Termination of the platform's growth and the local demise of platform-dwelling pholadid populations were brought about by progradation of a large volume of land-derived clastics (mostly igneous) triggered by tectonic uplift beginning about 2 m.y. ago. Granule to small pebble-size debris choked the entrance to pholadid horings and larger clasts blanketed the platform.

5. Graded beds broadly characterize the basal conglomerate, indicating the repetitious sorting of materials added in discrete pulses. Barnacle encrustation of clasts, in both the platform's seaward and landward margins, demonstrates the broad extent of marine influence and reinforces the interpretation of reworking by waves.

6. The platform deposit is wedge-shaped overall, with thicker accumulations of conglomerate in the seaward direction and thinner accumulations in the landward direction. This shape reflects final, full marine accommodation of the land-derived materials produced by tectonic uplift.

7. The siltstone platform is dissected from back to front by shallowly incised paleo-arroy$o$, indicating proximity to land.

8. The siltstone platform's seaward margin is dissected by runnels perpendicular to the paleo-shoreline, indicative of tidal activity.

All of the above features are brought into focus by the existence nearby of a present-day, intertidal abrasion platform eroded in a lower stratigraphic level of the same Cretaceous siltstone. Processes observable in this modern intertidal zone include boring activity by pholadid bivalves. emplacement of runnels by tidal activity. and the introduction of pebble- to cobble-size. land-derived clasts via a large. dissecting arroyo. During high tides, the clasts atop the landward margin of the modern platform undergo crude sorting by size.
(1992, pp. 265-277) lista observaciones sobre una docena de limolitas y lutitas del Plioceno, mayormente de la costa de Japón. Las tasas de erosión varian entre 0.13 y $2.05 \mathrm{~m} /$ año, bajo las condiciones presentes. Sin embargo, en promedio, la tasa de crosión intermareal para una litología tan suave es $0.90 \mathrm{~m} / \mathrm{año}$. Considerando condiciones intermareales similares durante la erosión en el plioceno de las lutitas de la formación Rosario del Cretácico, la plataforma sobre la cual yace la formación Cantil Costero puede haber sido desgastada $3 \mathrm{~km}$ hacia la tierra en tan solo 3,000 años. No quedó evidencia de un cantil marino de lutita después de esta transgresión.

\section{CONCLUSIONES}

Las plataformas de abrasión intermareales sin cantiles marinos en su parte posterior constituyen una categoría especial de costas rocosas. Las siguientes conclusiones sumarizan los atributos físicos de la plataforma de abrasión y la cubierta de la plataforma definidos para el Plioceno superior de la formación Cantil Costero.

1. La plataforma de abrasión se encuentra en una sola discontinuidad entre el conglomerado del Plioceno superior y las lutitas del Cretácico superior; no se presenta otro basamento intraformacional o diastema en niveles inferiores en la potente lutita cretácica.

2. La extensión lateral paralela a la costa del Plioceno es de más de $6 \mathrm{~km}$, con por lo menos $3 \mathrm{~km}$ de ancho. La discordancia investigada alcanza una superficie de más de $18 \mathrm{~km}^{2} \mathrm{y}$ está formada bajo condiciones de intermareales a submareales someras.

3. Durante la fase activa de abrasión de la plataforma, ésta se mantuvo limpia de detritus y la superficie de lutita fue extensamente colonizada por inmensas poblaciones de bivalvos foládidos perforadores a todo lo largo de la costa. La densidad de las poblaciones fue variable, pero la densidad máxima tuvo aproximadamente $200 / \mathrm{m}^{2}$. Muchos de los bivalvos pertenecientes a Penitella penita están aún intactos dentro de las perforaciones de hasta $10 \mathrm{~cm}$ de profundidad.

4. El fin del crecimiento de la plataforma y la disminución local de las poblaciones de 
A common characteristic of disconformity surfaces is partial erosion of the matrix around fossil borings, leaving only the bottom portion of the borings intact. By itself, this aspect is insufficient to settle the issue of intertidal as opposed to submarine abrasion. In the absence of associated sea cliffs, the preservation of runnels, channels or spurs on the disconformity surface helps establish the occurrence of abrasion under intertidal conditions. To this category must be added the larger-scale topography of platform-dissecting stream mouths or arroyos, as illustratcd in this report. A comparablc featurc occurring in limestone disconformities would be a calanque, or gorge-like coastal inlet influenced by stream outflow (Trenhaile, 1987). Last but not least in importance are any conglomerates associated with a disconformity surface. The shape of the conglomeratic deposit, evidence of internal sorting, and the remains of fossils all reflect on the environmental history of the disconformity. In this regard, the platform deposits of the Cantil Costero Formation provide an example of intertidal to shallow subtidal development on a large scale.

\section{ACKNOWLEDGEMENTS}

Field work leading to this article was undertaken in Baja California during January 1992, as part of a short course on rocky-shore paleoecology sponsored jointly by the Universidad Autónoma de Baja California at Ensenada and Williams College. Participating students from Mexico were Enrique Amaro-Franco, Jorge Candena-Lucero, Sergio Flores-Ramírez, Gabriel López-Morteo, René Palacios-Navarro and Carlos Santin-Domínguez. Participating students from the U.S. were Rachel J. Beane, Christopher M. Brookfield, Hovey C. Clark, Ir., Brenden J. Cowan, Rebecca M. Edwards, Thomas J. Ekman, Marshall L. Hayes, Leslie S. Heald and Paul A. Hohenlohe. We are grateful to Andrzej Radwanski (Warsaw University) for identifying the fossil pholadids and providing related literature. Victor A. Zullo (University of North Carolina at Wilmington) examined the fossil barnacles. Acknowledgement is made by Ledesma-Vázquez to UABC, for support through project 4026 (Rocky Shorelines in Baja (alifornia). and by Johnson to the donors of the foládidos perforadores ocurrieron a consecuencia de la progradación de un gran volumen de clásticos terrígenos (en su mayoría ígneos), propiciada por un levantamiento tectónico iniciado hace dos millones de años. Material que va de cantos rodados pequeños a arenas tapó la entrada de las perforaciones de foládidos y clastos más grandes recubrieron la plataforma.

5. Los estratos gradados caracterizan ampliamente al conglomerado basal, indicando la repetida clasificación de los materiales añadidos en pulsos discretos. El recubrimiento de clastos por balanos, en los márgenes distantes y próximos de la playa, demuestra la amplia extensión de la influencia marina y refuerza la interpretación de trabajo hecho por el oleaje.

6. El deposito de la plataforma tiene en conjunto forma acuñada, con acumulaciones más potentes de conglomerados en direccion al mar y acumulaciones menores en dirección a tierra. Esta forma refleja una distribución final por procesos marinos de los materiales terrígenos inyectados por el levantamiento tectónico.

7. I.a plataforma de lutitas es cortada de atrás para adelante por paleoarroyos someramente excavados, lo que indica la proximidad de la tierra.

8. El margen de la plataforma de lutita cercano al mar es cortado por canales perpendiculares a la paleolínea de costa, indicativos de actividad mareal.

Todas las características arriba descritas son remarcadas por la presencia cercana de una plataforma de abrasión intermareal activa en un nivel estratigráfico inferior, en la misma lutita del Cretácico. Los procesos observables en la zona intermareal presente incluyen la perforación del substrato por bivalvos foládidos, el emplazamiento de canales por actividad mareal y la introducción de clastos de tamaño de canto rodado a grava, de origen terrígeno, por medio de un amplio arroyo que corta los estratos. Durante la marea alta, los clastos que coronan el margen de la plataforma que da hacia tierra sufren una burda clasificación por tamaños.

Una característica común de las superficies de discordancia es la erosión diferencial de la matriz alrededor de las perforaciones fósiles, dejando sólo la porción inferior de las perforaciones intacta. Por sí mismo, este aspecto es insuficiente para establecer el origen de la for- 
Petroleum Research Fund (administered by the American Chemical Society) and to the Nils Anderson Fund for Latin American Studies (administered by Williams College), for shared financial support of this project. The authors thank the support of CONACYT-NSF, through project Spring 92.

\section{REFERENCES}

Beal, C.H. (1948). Reconnaissance of the geology and oil possibilities of Baja California, Mexico. Geological Society of America, Memoir 31, $138 \mathrm{pp}$.

Conrad, T.A. (1837). Descriptions of new marine shells from Upper California, collected by Thomas Nuttal, esq. Journal of the Philadelphia Academy of Natural Sciences, 7: 227-268.

Dorsey, R.J. (1991). Fission-track age constraints on young, rapid uplift of the Sierra de San Pedro Martir, northern Baja California, Mexico. Geological Society of America Abstracts with Programs (San Diego Meeting), 23(5): 194-195.

Fischer, R. (1990). Significado paleoecológico y geológico de perforaciones fósiles de bivalvos. Revista de la Sociedad Mexicana de Paleontologia, 3: 79-95.

Fletcher, C.J.N. (1988). Tidal erosion, solution cavities and exhalative mineralization associated with the Jurassic unconformity at Ogmore, South Glomorgan. Proceedings of the Geological Association, 99: 1-14

Gastil, R.G., Phillips, R.P. and Allison, E.C. (1971). Reconnaissance geologic map of the State of Baja California $(1: 250,000)$. Geological Society of America, 3 sheets.

Gastil, R.G., Phillips, R.P. and Allison, E.C. (1975). Reconnaissance geology of the State of Baja California. Geological Society of America, Memoir 140, $170 \mathrm{pp}$.

Gazdzicki, A., Gradzinski, R., Porebski, S.J. and Wrona, R. (1982). Pholadid Penitella borings in glaciomarine sediments (Pliocene) of King George Island, Antarctica. Neues Jahrbuch für Geologie und $\mathrm{Pa}$ leontologie Monatsheft, 12: 723-735.

Johnson. M.E. (1992). Studies on ancient rocky shores: A brief history and annoted bibli- mación de este deposito como intermareal $\mathrm{o}$, al contrario, como de abrasión submarina. En la ausencia de cantiles asociados, la preservación de canales de marea o salientes en la superficie de discordancia ayuda a establecer si ha ocurrido abrasión bajo condiciones intermareales. En esta categoría se ha de añadir la topografia de mayor escala de bocas de arroyos o corrientes que cortan la plataforma, como se ilustra en este informe. Una caracteristica comparable que se presenta en las discordancias en calizas sería un calanque o canal de acceso costero en forma de cañada influenciado por corrientes de reflujo (Trenhail, 1987). Por último, pero de igual importancia, es cualquier conglomerado asociado con una superficie de discordancia. La forma del depósito conglomerático evidencia la clasificación interna, y los restos de los fósiles en conjunto reflejan la historia ambiental de la discordancia. En este sentido, los depósitos de plataforma de la formación Cantil Costero proveen un ejemplo de desarrollo intermareal a submareal somero de gran escala.

\section{AGRADECIMIENTOS}

El trabajo de campo que originó este artículo se realizó en Baja California durante enero de 1992, como parte de un curso de paleoecología de las líneas de costa rocosa patrocinado conjuntamente por la Universidad Autónoma de Baja California (Ensenada), y el Williams College. Los estudiantes participantes fueron, por México, Enrique Amaro Franco, Jorge Candena Lucero, Sergio Flores Ramirez, Gabriel López Morteo, René Palacios Navarro, Carlos Santín Domínguez y, por Fstados Unidos, Rachel J. Beane, Christopher M. Brookfield, Hovey C. Clark, Jr., Brenden J. Cowan, Rebecca M. Edwards, Thomás J. Ekman, Marshall L. Hayes, Leslie S. Heald, Paul A. Hohenlohe. Nuestro agradecimiento a Andrzej Radwanski (Universidad de Varsovia) por identificar los foládidos fósiles y proveer la literatura relacionada con ellos, y a Victor A. Zullo (Universidad del Norte de Carolina, en Wilmington) por el examen de los fósiles balanos. Ledesma Vázquez agradece a la UABC el apoyo al proyecto 4026 (Líneas de costa rocosa en Baja California) y Markes Johnson agradece 
ography. Journal of Coastal Research, 8: 797-812.

Kelly, S.R.A. and Bromley, R.G. (1984). Ichnological nomenclature of clavate borings.

Palaeontology, 27: 793-807.

Kilmer, F.H. (1963). Cretaceous and Cenozoic stratigraphy and palcontology, El Rosario area, Baja California, Mexico. Dissertation, Berkeley, University of California, 216 pp. (Univ. Microfilms, Inc., No. 66-15526).

Lescinsky, H.L., Ledesma-Vázquez, J. and Johnson, M.E. (1991). Dynamics of Late Cretaceous rocky shores (Rosario Formation) from Baja California, Mexico. Palaios, 6: 126-141.

Lewy, Z. (1985). Paleoecological significance of Cretaceous hivalve horings from Israel. Journal of Paleontology, 59: 643-648.

Miller, V.V. and Abbott, P.L. (1989). Sedimentology of the Upper Cretaceous Rosario Formation near Colonet and Camalú, Baja California. In: P.L. Abbott (ed.), Geologic Studies in Baja California. Pacific Section Society of Economic Paleontologists and Mineralogists, Los Angeles, California, pp. 63-74.

Perkins, B.F. and Stewart, C.L. (1971). Whitestone Quarry. In: B.F. Perkins (ed.), Trace fossils, a field guide to selected localities in Pennsylvanian, Permian, Cretaceous and Tertiary rocks of Texas. Louisiana State University, School of Geoscience, miscellaneous publication, 71-1: 17-22.

Rose. P.R. (1970). Stratigraphic interpretation of submarine versus subaerial discontinuity surfaces: an example from the Cretaceous of Texas. Geological Society of America Bulletin, 81: 2787-2798. a los donantes del Petroleum Research Fund (administrado por la Asociación Química Americana) y de la fundación Nils Anderson para estudios en América Latina (administrada por Williams College) por el apoyo financiero compartido de cste proyecto. Los autores agradecen, además, el apoyo de CONACYT-NSF, por medio del convenio Primavera 92.

Traducido al español por los autores.

Santillán, M. y Barrera, T. (1930). Las posibilidades petrolíferas en la costa occidental de la Baja California, entre los paralelos $30^{\circ} \mathrm{y}$ $32^{\circ}$ de latitud norte. Anales del Instituto de Geología, UNAM, México, 37 pp.

Silver, L..I., Stehli, F.G. and Allen, C.R. (1963). Lower Cretaceous prebatholithic rocks of northern Baja California, Mexico. American Association of Petroleum Geologists Bulletin, 47: 2054-2059.

Sunamura, S. (1992). Geomorphology of Rocky Coasts. John Wiley \& Sons, New York, $302 \mathrm{pp}$.

Trenhaile, A.S. (1987). The Geomorphology of Rock Coasts. Clarendon Press, Oxford, $384 \mathrm{pp}$.

Valentine, J.W. (1955). Upwelling and thermally anomalous Pacific coast Pleistocene molluscan faunas. American Journal of Science, 253: 462-474.

Zullo, V.A. (1992). Revision of the balanid barnacle genus Concavus Newman, 1992, with the description of a new subfamily, two new genera, and eight new species. The Paleontological Society, Memoir 27, pp. 1-46. 